Article

\title{
English Adverbial and Determiner Negation: A Problematic Area for Arabic Translators
}

\author{
Mohammed Farghal \\ Department of English, Kuwait University, Jamal Abdul Nasser St, Kuwait City 13060, Kuwait; \\ m_farghal@hotmail.com
}

Received: 30 October 2018; Accepted: 1 March 2019; Published: 12 March 2019

check for updates

\begin{abstract}
Negation hardly comes up as an issue in English-Arabic translation studies. The general assumption is that the translation of English negation into Arabic poses no serious problems to the translator. While this is generally true when it comes to rendering negation marked by generic negative particles/affixes (John is not happy and John is unhappy, respectively) and even lexical and rhetorical implicit negation (John denied having cheated on the test and Can a person like John make such a mistake?), the present paper aims to show that the appropriate textualization into Arabic of English adverbial and determiner negation (e.g., by the adverbials too and hardly, and the determiners little and few) can be a problematic area for Arabic translators. The textual data ( 270 examples) is extracted from several published translations (belonging to literary, popular science/journalistic, and economic discourse), in an attempt to show what strategies translators follow when encountering such negation and how successful they are. While the findings provide solid evidence for the serious mishaps (about $42 \%$ of the renderings involve one kind of problem or another) that Arabic translators experience in this area, the critical discussion unravels several textual strategies that can capture the subtleties inherent in adverbial/determiner negation. It is hoped that the investigation of this subtle, neglected area in English-Arabic translation studies offers significant insights for both student and professional translators.
\end{abstract}

Keywords: adverbial negation; determiner negation; English; Arabic; translation

\section{Introduction}

There have been several studies which deal, among other things, with the linguistics of negation in Arabic, where negation is divided into explicit and implicit negation (Anees 1975; Al-Makhzumi 2016; Alsalem 2012; Muslah 2015). While explicit Arabic negation employs negative particles such as lam [did not], laa [do not], and lan [will not], implicit Arabic negation uses grammatical devices such as interrogatives and conditionals. However, there are only very few studies that have dealt with Arabic and English negation from a translational perspective (e.g., Dendane and Dendane 2012; Al-Ghazalli 2013). In particular, there are no studies, to my knowledge, that raise the question of English non-generic explicit negation by too and -ly adverbs and little and few determiners, which is supposed to be a problematic area because Arabic lacks this type of explicit negation.

The present study, therefore, aims to fill in this gap in English-Arabic translation studies by addressing itself to the translation of non-generic adverbial and determiner negation, as an area of contrast between English and Arabic that may cause serious problems. While English uses both explicit generic negation (negation by not and similar negative particles) and explicit non-generic adverbial/determiner negation, Arabic lacks the latter type as it exclusively employs explicit generic negation by negative particles, such as laa, laysa, lam, maa, lan, etc., which are all tense sensitive (laa and laysa in present, lam and maa in past (with lam [followed by imperfective verb form being used much more commonly in Modern Standard Arabic than maa (followed by perfective verb form)], and lan 
in future). It seems necessary, in such case, to examine English non-generic adverbial/determiner negation from a translational perspective in order to explore the translation strategies that translators resort to, when modulating this type of negation, in an attempt to capture its meaning and pragmatics. Such investigation is expected to have theoretical as well as practical implications for people working in English-Arabic translation studies, and may also prompt future investigations between English and other languages that lack this type of negation.

The study is structured as follows. Section 2 reviews the related literature from both a linguistic and a translational perspective. Section 3 presents the research questions. Section 4 describes the textual materials used. Section 5 offers a detailed analysis of the data. Section 6 discusses the findings. Finally, Section 7 concludes the study.

\section{Review of Literature}

Negation, whose universality is unanimously confirmed in the existing literature on human language (Dahl 1979; Payne 1985; Horn and Kato 2000; Horn 2001, among others), is generally considered an operator that reverses the truth value of a proposition. It is a unique property of human language: "Negative utterances are a core feature of every system of human communication and of no system of animal communication" (Horn and Kato 2000, p. 1). Linguists (Klima 1964; Clark 1976; Horn 2001, among others) usually divide negation into two types: explicit negation and implicit negation. On the one hand, explicit negation employs explicit negative particles such as not (as in John did not go shopping), negative affixes such as -il in This act is illegal, or other negative adverbs, for example, hardly (as in John hardly knows anything about mathematics) or determiners, for example, few (as in John has only few friends). On the other hand, implicit negation is implied semantically (as in John prevented his daughter from joining the club, which semantically entails John did not allow his daughter to join the club) or implicated pragmatically (as in the rhetorical question Should we keep silent after all these heinous crimes, which conversationally implies We should not keep silent after all these heinous crimes).

Similarly, Arabic negation is divided into explicit and implicit negation. While English verbal negation is uniform in nature, as it only employs the negative particle not in such negation (viz. John does not go to school, John did not go to school, and John will not go to school), its Arabic explicit counterpart is highly diversified (for details about Arabic negation, see Anees 1975; Al-Makhzumi 2016; Alsalem 2012; Muslah 2015), viz. لا يذهب جون إلى المدرسة laa yaðhabu joon 'ilaa al-madrasati [not

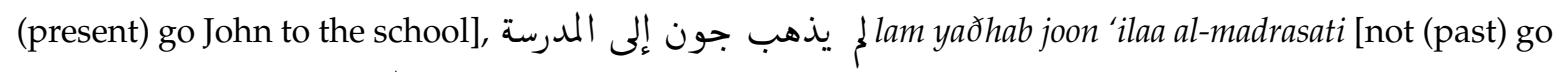
John to the school], لن يذهب جون إلى المدرسة lan yaðhaba joon 'ilaa al-madrasati [not (future) go John to the school]. Al-Makhzumi (2016, p. 265), for example, defines negation as "a linguistic category which is opposed to affirmation and intended to disprove or deny the truth value of a proposition". Explicit لم يكتب/ ما كتب سالم الرسالة. Arabic negation employs negative particles such as lam and maa [did not] (e.g., lam yaktub/maa kataba Saalimun 'ar-risaalata [Negative particle (NEG) write/NEG wrote Salim the-letter]

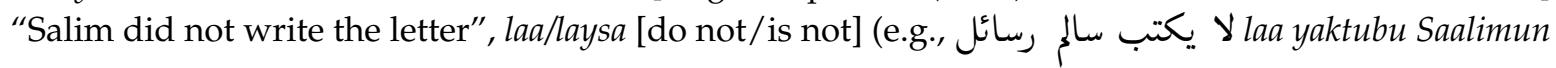

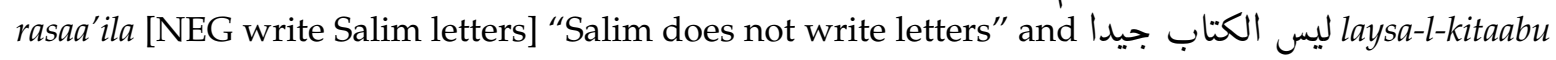

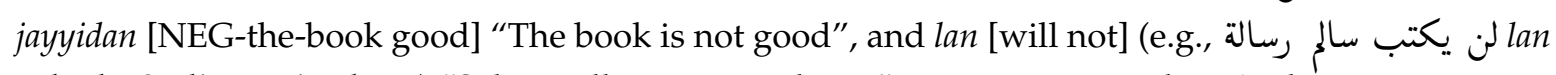
yaktuba Saalimun risaalatan) "Salim will not write a letter". By contrast, implicit Arabic negation uses grammatical devices such as interrogatives (e.g., هل يتساوى الخير والشر hal yatasaawa-l-xayru wa-̌̌-šarru? [Question word (Q) equal-the-good and-the-evil] "Are the good and evil equal?" and conditionals (e.g., لو كنت موجوداً لأخبرته law kunto mawjuudan la-'xbartu-hu [if was(I) present so-told-him(I)); both examples involve implicit negation, viz. the answer to the question must be in the negative (No, they are not equal), and the latter statement implies that the speaker had not been there. Nevertheless, this fact does not cause any serious problems for the translator into Arabic because the one-to-many correspondence between the negative particles is obvious, being tense oriented in Arabic. 
Notably, while Arabic translation correspondents are usually accessible for generic negation, e.g., John does not adhere to punctuality / لا يلتزم جون بالمواعيد laa yaltazimu joon bi-l-mawaa'iidi [not (present) adhere John to-the-punctuality], affixal negation, for example, John is unhappy/ جون غير سعيد joon rayru sa'iidin [joon not happy], and implicit negation (Arabic being as highly lexicalized as English), for example, John declined the offer/رفض جون العرض rafada joon al-'arda [declined john the-offer], which semantically entails John did not accept the offer and الم يقبل جوض العرض lam yaqbal joon al-'arda [not (past) accept John the-offer], respectively. However, the translator is required to modulate (Vinay and Darbelnet 1995) or look for translation equivalents (Koller 1979) in the case of adverbial/determiner negation by usually retrieving negation (whether explicit or implicit) in Arabic. For example, the adverbial negation by too in John was too ambitious needs to be modulated by recovering generic negation in Arabic as in lam yakun joon waaqi'iyyan fii țumuuhaati-hi

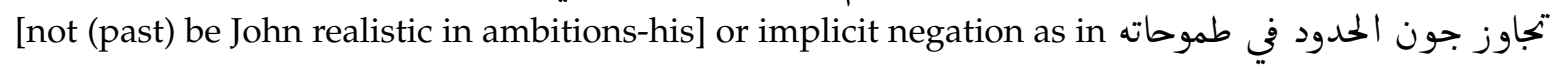
tajaawaza joon al-huduuda fii țmuuhaati-hi [exceeded John the-limits in ambitions-his]. Similarly, the determiner negation in John has little interest in politics needs to be modulated into generic negation as in laysa ladaa joon 'illa-l-qaliilu min al-'ihtimaami fis-siyaasati

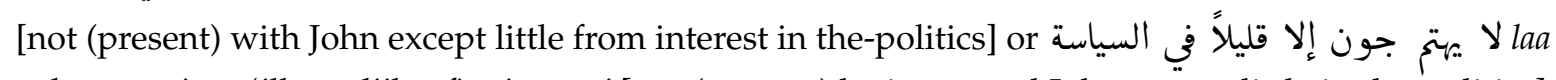
yahtammu joon 'illaa qaliilan fis-siyaasati [not (present) be interested John except little in the-politics], or implicit negation as in ينأى جون بنفسه عن الاهتمام في السياسة yan'aa joon bi-nafsihi 'an-il-'ihtimaami fis-siyaasati [alienates John with-himself from the-interest in the-politics].

In terms of translation, there are only very few studies on the translation of negation. Apostolatu and Apostolatu (2012) deal with literary translation of English negation into Romanian. They show that some negative markers are sometimes unjustifiably omitted, which is usually caused by the differences between the two languages involving negative polarity, scope of negation, and double negation. Dendane and Dendane (2012) refer to the one-to-many correspondence between the English particle not and the many counterparts in both standard and vernacular Arabic, which causes serious problems to machine rather than human translation. Li (2017) points out the difficulty Chinese English foreign language (EFL) learners face when expressing adverbial negation by too due to its Chinese counterpart, which functions as an intensifier. Hence, Chinese learners often erroneously employ the negative adverb too instead of the intensifier "very" or "so" (e.g., "The party was too good" may be used to mean "The party was very/so good").

A similar mishap may occur in English-into-Arabic translation. Farghal and Almanna (2015a, p. 27) briefly examine negation while discussing syntactic features in translation. Whereas they state that English generic negation by not is not problematic when rendering it into Arabic, despite the existing one-to-many correspondences, it is argued that the negation embedded in too can pose a challenge because it requires a translation strategy that recovers negation in Arabic, whether explicitly or implicitly. To demonstrate this point, they give the following example from a published translation in which the negation is missed by replacing the negative adverb too with the Arabic intensifiers jiddan [very] (a list of Arabic phonetic symbols (mainly International Phonetic Alphabet (IPA)) is provided in Appendix A):

1. I think you've been too busy to notice where I have been.

\begin{tabular}{|c|c|c|}
\hline $\begin{array}{l}\text { 'a } \partial \text { unnu 'anna-ka kunta maš } \gamma \text { uulan } \\
\text { think (I) that-you be-you busy }\end{array}$ & $\begin{array}{l}\text { jiddan li-tulaahiða } \\
\text { very to-notice }\end{array}$ & $\begin{array}{l}\text { 'ayna 'anaa } \\
\text { where I }\end{array}$ \\
\hline
\end{tabular}

"I think you were too busy to notice where I am".

$$
\text { أظن أنك كنت مشغولاً جداً لتلاحظ أين أنا. }
$$

Al-Ghazalli (2013) discusses the translation of Arabic implicit negation where he unjustifiably argues for unpacking Quranic implicit negation in rhetorical questions. According to his analysis, the 
Quranic verse هل يستوي الأعمى والبصير hal yastawi-l-'a'maa wa-l-baṣiir [Q equal the-blind and-the-sighted] is erroneously rendered as a generic rather than a rhetorical question by Quran translators as in Yousef Ali's Can the blind be held equal to the seeing (p. 135) and M. Pickthal's Are the blind and the seer equal (p. 133). Therefore, he claims, implicit negation should be made explicit as in Are the blind and the one who sees equal? Definitely, this is not true (p. 139). Needless to say here, that mainstream translation theorists (Nida 1964; Catford 1965; Newmark 1988; Baker 1992; Hatim 1997; Dickins et al. 2002; Pym 2010; Munday 2012; Farghal 2012; Farghal and Almanna 2015b; Farghal et al. 2015, among others) emphasize the translator's ability to call up textual/functional material in the target language (TL) that effectively relays its counterpart in the source language (SL). One should note that, textually as well as functionally, Arabic rhetorical questions readily translate into English rhetorical questions (Ali's and Pickthal's above), thus remaining within the scope of implicit rather than explicit negation.

\section{Research Questions}

Due to the fact that English adverbial and determiner negation has no formal translational equivalent in Arabic and the lack of studies in this area, the purpose of this study is to explore the translation strategies that translators employ when rendering such negation into Modern Standard Arabic and examine how successful these strategies are. In particular, the study aims to check whether Arabic translators retrieve explicit negation (or alternatively use implicit negation) when modulating adverbial and determiner negation in an attempt to capture the pragmatics of this type of negation. Specifically, the following research questions are addressed in this paper:

1. How do Arabic translators tackle too adverbial negation in terms of translation strategies?

2. How do Arabic translators render English -ly adverbial negation in terms of translation strategies?

3. What translation strategies do Arabic translators follow in rendering little determiner negation?

4. Finally, are Arabic translators sensitive to few determiner negation?

\section{Textual Materials}

This is an empirical study based on the extraction of ample textual data involving English adverbial/determiner negation along with their target Arabic counterparts from existing works and their translations. The textual data (270 examples) features two types of markers of adverbial negation (too and hardly/scarcely/barely) and two markers of determiner negation (little and few). The study provides both a quantitative and a qualitative analysis of the data. It should be noted that the qualitative discussion almost exclusively focuses on the rendering of the items under study which belong to adverbial and determiner negation, apart from the general quality of the translation, which is not within the scope of this study.

The sources of the textual data include five series of Harry Potter (HP, henceforth) by J. K. Rowling, namely Harry Potter and the Philosopher's Stone (1; Rowling 1997), Harry Potter and the Prisoner of Azkaban (2; Rowling 1999), Harry Potter and the Chamber of Secrets (3; Rowling 1998), Harry Potter and the Order of Phoenix (4; Rowling 2003), and Harry and the Half-blood Prince (5; Rowling 2005). The first and the third series are translated by Ragaa Abudullah. The second series is translated by Hasan Ahmed Mohammed, the fourth by Idaarit Al-Nashr and the fifth by Abd Al-Wahab Aloob (see references for complete information). The textual data sources also include The Blue Flower (BF) by Fitzgerald (1995) (translated by Ali Suleiman), The Fault in our Stars (FS) by Green (2012) (translated by Baseel Intwan), The Help (TH) by Stockett (2009) (translated by Hassan Al-Bustani), The Future: Six Drives of Global Change (GC) by Gore (2013) (translated by Adnan Gergeos), and The Making of Economic Society (ES) by Heilbroner (1962) (translated by Rashid Al-Barrawi).

The choice of the textual data is motivated by the different genres it belongs to, viz. literary, popular science/journalistic, and economic, as well as the different translators involved in translating it. The aim is to investigate a representative sample of textual material in terms of genre and translators 
in order to come up with generalizations about the translation of adverbial and determiner negation across several genres and translators.

\section{Analysis}

The analysis examined the translation strategies employed by the translators in rendering adverbial and determiner negation in terms of frequency and percentage, which gave a clear picture about their utility when encountering such negation. First, Section 5.1 presented the markers of adverbial and determiner negation and their distribution in the English corpus. Second, Section 5.2 examined the translation strategies employed in rendering too adverbial negation, using both explicit negation (Section 5.2.1) and implicit negation (Section 5.2.2). Third, Section 5.3 looked at how the translators dealt with -ly adverbial negation in terms of translation strategy. Fourth, Section 5.4.1 investigated how the translators had tackled little determiner negation and the translation strategies adopted. Finally, Section 5.4.2 considered few determiner negation and how sensitive the translators had been to this type of negation.

\subsection{Adverbial and Determiner Negative Markers}

In terms of the type of negative marker, the English corpus is distributed as shown in Table 1 below.

Table 1. Distribution of English negative markers in the corpus.

\begin{tabular}{cccc}
\hline & Marker & Frequency & Percentage \\
\hline 1 & Too & 100 & $37 \%$ \\
2 & Hardly & 34 & $12.60 \%$ \\
3 & Scarcely & 19 & $7 \%$ \\
4 & Barely & 11 & $4 \%$ \\
5 & Little & 86 & $31.85 \%$ \\
6 & Few & 20 & $7.40 \%$ \\
& Total & 270 & $100 \%$ \\
\hline
\end{tabular}

Table 1 shows that adverbial negation by too is the most frequent in the corpus (37\%) followed by determiner negation by little (31.85\%). Third comes adverbial -ly negation including hardly, scarcely, and barely which together account for (23\%). Within -ly negation, hardly emerges as the most frequent $(12.60 \%)$, followed by scarcely $(7 \%)$, then barely $(4 \%)$. The least frequent in the data is determiner negation by few, which only accounts for $(7.40 \%)$. These percentages may only give us a preliminary picture about the frequency of adverbial/determiner negation in English discourse. To affirm such frequencies, a large scale quantitative and qualitative corpus linguistics investigation needs to be carried out, which is far beyond the scope of the present study.

\subsection{Translating Adverbial Negation by Too}

\subsubsection{Explicit Negation}

Table 2 below presents the frequency and percentage of employing translation strategies in rendering too adverbial negation.

Table 2. Frequency and percentage of explicit negation strategies in rendering too negation.

\begin{tabular}{lcc}
\hline \multicolumn{1}{c}{ Translation Strategy } & Frequency & Percentage \\
\hline a. Unpacking by coordination & 17 & $36.17 \%$ \\
b. Nominalization in simple/complex structures & 15 & $31.91 \%$ \\
c. Indicating degree of attribute & 11 & $23.40 \%$ \\
d. Mistranslations/under-translations & 4 & $8.51 \%$ \\
\hline
\end{tabular}


Table 2 above shows that there are three main translation strategies adopted by Arabic translators when opting to render English too negation by explicit Arabic negation: (1) Unpacking by coordination, (2) nominalization in simple or complex structures, and (3) indicating degree of attribute.

Firstly, unpacking too negation by a coordinate Arabic structure featuring explicit negation is the most frequent translation strategy at $36.17 \%$ (17 cases) for rendering too negation. It proves to be a workable strategy, as can be observed in the following example:

2. Harry was too deeply asleep to hear her. (HP/4)

\begin{tabular}{|c|c|c|c|}
\hline $\begin{array}{l}\text { haarii } \\
\text { Harry }\end{array}$ & $\begin{array}{l}\text { kaana } \\
\text { was }\end{array}$ & $\begin{array}{l}\text { raariqan } \\
\text { sinking }\end{array}$ & $\begin{array}{l}\text { fii nawmi-hi fa-lam yasma 'a-haa } \\
\text { in sleep-his so-not hear-her }\end{array}$ \\
\hline
\end{tabular}

"Harry was deeply asleep, so he didn't hear her"

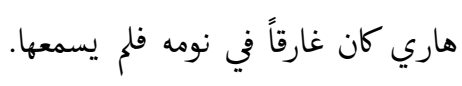

It is possible, also, to relay too negation in such cases by maintaining the English complex structure (second strategy below), as is shown in the rephrasing of (2) below, with a shift of focus in the ordering of the two propositions:

3. lam yasma '-haa haarii li'anna-hu kaana $r$ aariqan fii nawmi-hi

not hear-her Harry because-he was sinking in sleep-his

"Harry didn't hear her because he was deeply asleep"

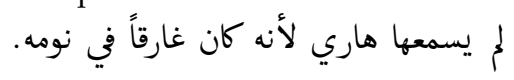

Secondly, nominalization in simple or complex Arabic structures comes second at $31.91 \%$ ( 15 cases). The translators have mostly succeeded in capturing too negation using this strategy, as can be noted in the examples below:

4. I was too late to save the girl. (HP/3)

lam 'astati ' 'inqaa $\partial$-1-fataati fi-l-waqti-l-munaasib

not be able saving-the-girl-in-the-time-suitable

"I couldn't save the girl at the right time".

$$
\text { لم أستطع إنقاذ الفتاة في الوقت المناسب. }
$$

5. $\ldots$ but his Patronus was too feeble to drive the dementor away. (HP/2)

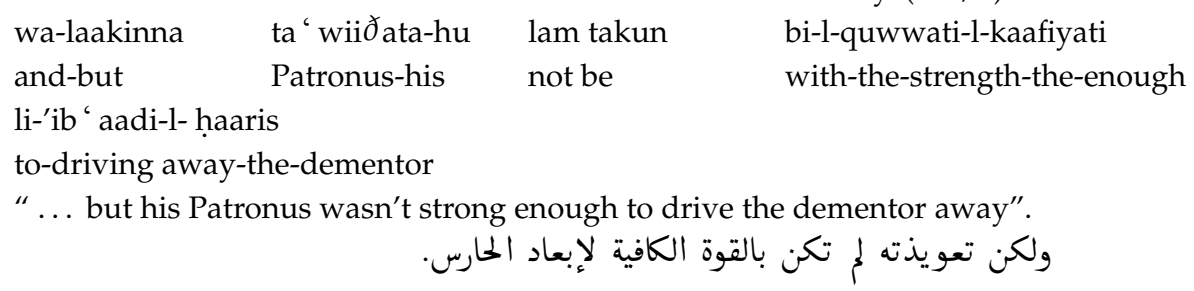

Thirdly, capturing too negation by indicating the degree of the attribute in question accounts for $23.40 \%$ (12 cases) of the examples in this category. Semantically, it corresponds to awkwardly rephrasing too negation by using the phrase to the extent that with negation by not in English, viz. John was too short to touch the ceiling may awkwardly be rephrased as John was short to the extent that he couldn't touch the ceiling. In Arabic, this strategy proves very useful for rendering too negation. The following example is illustrative:

6. Professor Trelawney seemed too tipsy to have recognized Harry. (HP/5) badat al-'ustaaðatu triiloonii maxmuuratun li-darajati 'anna-ha lam ta ' rif haarii seemed the-professor Trelawney drunk to-extent that-she not know Harry "Professor Trelawney was drunk to the extent that she didn't recognize Harry".

$$
\text { بلدت الأستاذة تريلوني مخمورة لدرجة أنها لم تعرف هاري. }
$$


Finally, let us look at one example where the translator has failed to capture the subtlety of too negation by reducing it to generic Arabic negation, viz. " ... but Harry was too used to this to care" is rendered into wa-laakina haari lam yahtam bi-haaðaa [and-but Harry NEG care in-this] "but Harry did care about this". As can be seen, the translator has managed to recover explicit Arabic negation but failed to capture the meaning of too negation. To do this, one may suggest wa-laakina haari lam yahtam li-ta 'awwudi-hi 'alaa haaðaa [and-but Harry NEG care because-being used to-him on this] " . . but Harry did not care because he was used to this".

\subsubsection{Implicit Negation}

Table 3 below displays the frequency and percentage of using implicit negation translation strategies when rendering too adverbial negation.

Table 3. Frequency and percentage of implicit negation strategies in rendering too negation.

\begin{tabular}{lcc}
\hline \multicolumn{1}{c}{ Translation Strategy } & Frequency & Percentage \\
\hline a. Using comparative form & 16 & $28.80 \%$ \\
b. Using negative verbs & 11 & $20.75 \%$ \\
c. Indicating degree of attribute & 10 & $18.87 \%$ \\
d. Mixed bag (mistranslations/under-translations) & 16 & $30.19 \%$ \\
\hline
\end{tabular}

Apart from the mixed bag of erroneous translations/under-translations (16 instances, 30.19\%), Table 3 indicates that there are three main implicit negation strategies for capturing the meaning of too negation: (1) Employing the comparative form, (2) employing negative verbs, and (3) indicating degree of attribute.

The translation strategy using the Arabic comparative form (16 instances, 28-30\%) emerges as very useful for handling too negation. The comparative Arabic forms 'af' al min [more of an attribute than] and 'ak $\theta$ ar mașdar (verbal noun) min [more of verbal noun than] here capture the nuance that the force of $X$ 's attribute goes beyond the capability of Act $Y$, for example, 'aðkaa min 'an yuxda ' [cleverer than that (he) be deceived] and 'akӨara ðakaa'an min 'an yuxda' [(has) more cleverness than that (he) be deceived] which both idiomatically translate into Ali is too clever to deceive. Following are two illustrative examples from the corpus:

7. ... because it was too long to memorize. (FS)

$\begin{array}{lll}\text {.. li'anna-ha 'ațalu min 'an tuhfa } \underline{\partial} a & \text { rayban } \\ \ldots \text { because-it longer from that be learned } & \text { by heart } \\ \text { "... because it was longer than it could be memorized". } & \end{array}$

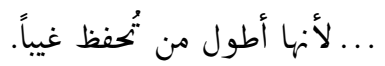

8. My way of life here is pitched too high for his young head. (BF) 'inna hayaatii hunaa 'akӨara șaxaban min 'an yaḥtammalu-ha ra'sa-hu-l-yaafi ' verily life-my here More noisy from that tolerated-it head-his-the-young "Indeed, my life was more noisy than what his young head could tolerate".

$$
\text { إن حياتي هنا أكثر صحباً من أن يتحملها رأسه اليافع. }
$$

The second translation strategy utilizes negative verbs/verbals (11 instances, 20.75\%) to relay the meaning of too negation. This is a familiar strategy in English as well as in Arabic to express negation implicitly rather than explicitly. For example, "the act of denying doing something" implies "the act of not admitting doing it". Consequently, this strategy constitutes an important option when translating negation in general and too negation in particular. The two examples below are illustrative: 
9. Anna dies or becomes too ill to continue writing it. (FS)

$\begin{array}{lll}\text { 'aana maatat } & \text { 'aw balarat min-al-maradi } & \text { haddan haala bayna-haa } \\ \text { Anna died } & \text { or reached from-the-illness } & \text { degree prevented between-her }\end{array}$

wa-bana-l-'istimraari fi-l-kitaabati

and-between-the-continuing in-the-writing

"Anna died or reached a degree of illness that prevented her from continuing writing".

$$
\text { آنا ماتت أو بلغت من المرض حداً حال بينها وبين الاستمرار في الكتابة. }
$$

10. It just seemed too good to be true that he was going to be rescued from the Dursleys. (HP/5) fa-qad badaa 'anna 'inqaaða-hu min 'aalii duurislii ‘amrun yafuuqu 'ahlaama-hu so-? seemed that rescuing-him from family Duresleys matter exceeds dreams-his "It seemed that rescuing him from the Duresleys was something that exceeds his dreams".

$$
\text { فقد بدا أن إنقاذه من آلي دوريسلي أمر يفوق أحلامه. }
$$

The implicit negation in (9) and (10) is achieved by the use of the negative verbs haala [prevented] and yafuuqu [exceed], which both imply propositions employing explicit negation in Arabic.

The third translation strategy employs the degree of the relevant attribute (10 instances, 18.87\%) as a marker of implicit negation by using the degree formulas min + masdar [verbal noun], for example, from the-smallness [i.e., too small] and verb/adjective + ' alaa [on], for example, (grow) old on [i.e., too old]. Observe the two examples below:

11. Fines for violations were too small to be effective, ... (ES)
fa-l-raraamaat-u ' an-il-muxaalafaati
kaanat min-aș-șir ari bihay $\theta u$
faqadat faa ' iliyyata-ha

so-the-fines from-the-violations

were from-the-smallness so

lost(they) effect-their

"The fines for violations were so small that they lost their effect"

$$
\text { فالغرامات عن المخالفات من الصغر .حيث فقدت فاعليتها. }
$$

12. “No, now I am too old to learn anything." (BF)

laa wa-'anaa al'aana kabirtu ' alaa ta ' allumi 'ayyi šay'in

no and-I now grew old on learning any thing

"No, I have grown (too) old to learn anything".

$$
\text { لا وأنا الآن كبرت على تعلم أي شيء. }
$$

Finally, we have the mixed bag, which includes mistranslations/under-translations that account for 16/53 instances (a full 30.19\%) in the cases of implicit negation. The two examples below are illustrative:

13. but it'll take too long to explain now. (HP/3)

$\begin{array}{lll}\text { laakinna-haa } & \text { qișsatun } & \text { țawiilatun } \\ \text { but-it } & \text { story } & \text { long }\end{array}$

"but it was a long story".

$$
\text { لكنها قصة طويلة. }
$$

14. It is still far too cold to undress at night. (BF)
laayazaalu-t-taqsu
baaridan
jiddan
li-xal 'i- $\theta-\theta$ iyaabi
fi-l-layli
still-the-weather
cold very
to-take off-the-clothes
in-the-night

"The weather is still very [too] cold to take off clothes at night"

$$
\text { لايزال الطقس بارداً جداً لحلع ثياي في الليل. }
$$




\subsection{Translating -ly Negation}

Table 4 presents the translation strategies which Arabic translators employ when rendering English -ly negation.

Table 4. Frequency and percentage of translation strategies in rendering -ly negation.

\begin{tabular}{ccc}
\hline Strategy & Frequency & Percentage \\
\hline Correct explicit negation & 12 & $18.75 \%$ \\
Under-translated explicit negation & 16 & $25 \%$ \\
Vernacular (ungrammatical) bilkaad & 20 & $31.25 \%$ \\
Correct implicit negation & 12 & $18.75 \%$ \\
Mistranslations/omission & 4 & $6.25 \%$ \\
Total & 64 & $100 \%$ \\
\hline
\end{tabular}

The sample of negative adverbs (which is extracted from BF, FS, GC, and ES, to the exclusion of HP) includes 34 instances of hardly, 19 of scarcely, and 11 of barely, coming to a total of 64 instances. These adverbs share the fact that they communicate a negative orientation when used in English sentences. That is why they are often interchangeable, albeit they may be sensitive to normality conditions (i.e., one may sound natural in one context, while another may not). For example, John was barely 17 when he joined college is natural, whereas John was scarcely 17 when he joined college is not. In terms of translation, the focus is on relaying the negative orientation which is shared by all of them.

Table 4 above shows only two successful strategies the translators have employed in rendering -ly negation: (1) Correct explicit negation (12 instances, 18.75\%), and (2) correct implicit negation (12 instances, 18.75\%). The remaining cases go for: (1) Inappropriate vernacular bilkaad (20 instances, $31.25 \%)$, (2) under-translated explicit negation (16 instances, 25\%), and (3) mistranslations (three instances) and omission (one instance), together $6.25 \%$.

Let us start with cases where -ly negation is accounted for in Arabic (12/28 instances, $42.85 \%)$ using correct explicit negation. The following examples are illustrative:

15. ... this little kid who could barely walk ... (FS)

... haaða-t-tiflu-ș-ṣa riiru 'allaðii laa yakaadu yamšii ...

... this-the-kid-the-little who not hardly walk...

"... this little kid who can hardly walk..."

$$
\text { ...... هذا الطفل الصغير الذي لا يكاد يمشي "... }
$$

16. The economics of society ... was hardly such as to provoke the curiosity of a thoughtful man. (ES)

kaanat 'iqtiṣaadiyyaat-ul-mujtama ' i ... takaadu laa tuӨiiru fuḍula rajulin mufakkirin were economics-the-society ... hardly not provoke curiosity man thoughtful

"The economics of society ... could hardly provoke the curiosity of a thoughtful man".

$$
\text { كانت اقتصاديات المجتمع ... تكاد لا تثير فضول رجل مفكِر. }
$$

The translators of (15) and (16) have successfully employed a negated yakadu, viz. laa yakaadu [not hardly] and takaadu laa [hardly not], which exactly capture the meaning of the -ly negation in them. One should note that yakaadu is an Arabic defective verb which translates into the negative adverb hardly when it is negated in Arabic, while it translates into almost/nearly when it is not negated, for example, kaada 'an yasquṭa fi-l-birkati [almost (he) that fall in-the-pool] "He almost/nearly fell in the pool". The negated yakadu proves so useful when rendering English -ly negation.

However, -ly negation does not seem as straightforward as (15) and (16) may suggest. While capturing the notion of negation in general, almost $58 \%$ of the Arabic renderings (16/28 instances) fail to account for the nuance inherent in -ly negation. Instead, this kind of negation is erroneously 
relayed as Arabic negation that corresponds to English negation by not, thus amounting to serious under-translations. Following are some illustrative examples:

17. The children of large families hardly ever learn to talk to themselves aloud, ... (BF) $\begin{array}{lll}\text { lam yata ' allam 'awlaadu-1- ' aa'ilaati-l-kabiirati } & \text { 'an yatahadda } \theta \text { uu } & \text { ilaa 'anfusihim } \\ \text { not learned children-the-families-the-big } & \text { that talk } & \text { to themselves }\end{array}$ bi-șawtin masmuu' in ... with-voice audible...

"The children of large families did not learn to talk to themselves in an audible voice ... "

$$
\text { لم يتعلم أولاد العائلات الكبيرة أن يتحدثوا إلى أنفسهم بصوت مسموع. }
$$

18. The Freifrau scarcely heeded her. (BF) lam tubaali-l-baaruunatu bi-haa not heed-the-Baroness with-her "The Baroness did not heed her".

$$
\text { لم لمبالي البارونة بها. }
$$

By way of illustration, in (17) the translator obliterates the subtle nuance of the negation in hardly by opting for explicit Arabic negation by lam [not]followed by the main lexical verb yata ' allam [learn], which back-translates into English negation by not, viz. "The children of large families did not learn to talk to themselves ..." ". To capture the negation inherent in hardly, one may need to employ a negated yakaadu viz. laa yakaadu 'awlaadu-l- ' aa'ilaati-l-kabiirati yata' allamuuna-t-tatahaddu $\theta a$ 'ilaa 'anfusihim bi-ṣawtin masmuu' in ... [not hardly children-the-families-the-large learn-the-talking to themselves with-voice audible] "The children of large families hardly learn to talk to themselves in an audible voice ... ". Or, alternatively, one may use a paucity adverb like naadiran maa and qalamaa [rarely], which both inhere the nuance that "the circumstances in which those children live hardly allow them to talk to themselves", viz. نادراً ما/قلما يتعلم أو لاد العائلات الكبيرة التحدث إلى أنفسهم بصوت مسموع naadiran maa/qallamaa yata 'allamu 'awlaadu-l- ' aa'ilaati-l-kabiirati at-tatahaddu $\theta a$ 'ilaa 'anfusihim bi-ṣawtin masmuu 'in ... [rarely/hardly learn children-the-families-the-large the-talking to themselves with-voice audible] "Rarely/hardly (do) the children of the large families learn to talk themselves in an audible voice".

The second strategy for rendering -ly negation is the employment of the vernacular negative adverb bilkaad, which is a malformed version of the standard la yakaadu. The question is whether it is appropriate to use a vernacular form when it is possible to utilize the standard negated yakaadu. What is surprising here is the absence of this vernacular form in Harry Potter's translation where the informal register may sanction it and the frequency of using it in the other works-it accounts for $31.25 \%$ of the -ly data (20/64 instances). By way of illustration, the example in (31):

19. I hardly know you, Augustus Waters. (FS)

$\begin{array}{lll}\text { 'anaa bilkaad } & \text { a 'rifu-ka } & \text { yaa 'urustus wuutarz } \\ \text { I hardly } & \text { know(I)-you } & \text { oh Augustus Waters } \\ \text { "I hardly know you Augustus Waters". } & \end{array}$

"I hardly know you Augustus Waters".

$$
\text { أنا بالكاد أعرفك يا أوغسطس ووترز. }
$$

can readily be rephrased naturally in standard Arabic using the negated yakaadu as in (20) below.
20. 'anaa laa 'akaadu a 'rifu-ka yaa 'u rusțus wuutarz
I not hardly(I) know(I)-you oh Augustus Waters

"I hardly know you Augustus Waters".

$$
\text { أنا لا أعرفك أكاد يا أوغست ووترز. }
$$


Next, we have the strategy of implicit negation which accounts for $18.75 \%$ in the -ly negation data (12/64 instances). They mainly employ paucity or difficulty expressions in an attempt to capture the negative nuance inherent in -ly negation. Consider the two examples below:

21. Auguste nowadays scarcely ever went out at all, ... (BF)

fii miӨli haaðihi-1-'ayyaami kaana min-an-naadiri bi-nnisbati li-'uu $\gamma$ ast

in like these-the-days was from-the-rarity as-regards to-Auguste

'an taðhaba xaariji-l-manzili

that go(she) outside-the-house

"In these days Auguste rarely leaves home".

$$
\text { في مثل هذه الأيام كان من النادر بالنسبة لأوغست أن يذهب خارج المنزل. }
$$

22. It is asked incessantly, most of the time however hardly noticeably, ... (BF)

su'aalun yus'alu bi-stimraarin rarma 'anna-hu yulaaḥago u bi-ṣu 'uubatin ... question be asked with-continuity despite that-it be noticed with-difficulty ...

"A question asked incessantly despite (the fact that) it is noticed with difficulty ... "

$$
\text { سؤال يسئل باستمرار رغم أنه يلاحظ بصعوبة ... }
$$

In (21), the translator successfully employs a paucity expression min-al-naadiri [from the rarity] to capture -ly negation. One should note that a negated yakaadu can be readily used for that purpose,

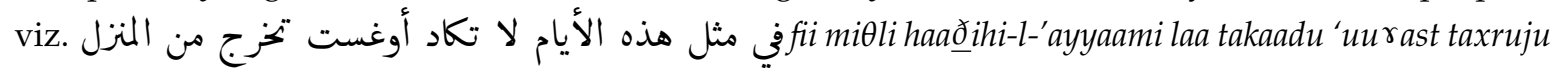
min-al-manzili [in like these days Auguste not hardly goes out from-the-house] "In these days Auguste hardly ever goes out". In (22), a difficulty expression bi-șu 'uubatin [with difficulty] is utilized. The difficulty expression approximates rather than replicates -ly negation. A negated yakaadu would capture the meaning more closely, viz. سؤال يسئل باستمرار رغم أنه لا يك su'aalun yus'alu bi-stimraarin rarma 'anna-hu laa yakaadu yulaahad $u$ [question be asked with-continuity despite that-it not hardly be noticed] "A question (that is) asked incessantly, despite the fact that it is hardly noticed, ... ".

To close this section, let us examine two mistranslations (out of three) which are found in the -ly negation data (they all come from ES) below:

23. This hardly seems like a particularly exciting subject for historical scrutiny.

$\begin{array}{lllll}\text { yakaadu } & \text { haaðaa } & \text { 'ašbaha } & \text { bi-mawduu' in } & \text { muӨiirin bi-wajhin xașsin } \\ \text { hardly } & \text { this } & \text { like } & \text { with-subject } & \text { exciting with-face particular }\end{array}$

lil-bahӨi-l-taariixiyyi

for-research-historical

"This almost seems like a particularly exciting subject for historical research".

$$
\text { يكاد هذا أشبه بموضوع مثير بوجه خاص للبحث التاريني. }
$$

24. This is particularly true when we begin at the stage of scarcely-better-than-subsistence...

wa-haaðaa șahiihun bi-wajhin xașșin 'indamaa nabda'u marhalata

and-this true with-face particular when begin(we) stage

maa yakaadu yaziidu 'alaa mujarradi-1- ' ayši ...

which hardly more than mere-the-livelihood ...

"This is particularly true when we begin the stage which is almost beyond mere livelihood ... "

$$
\text { وهذا صحيح بوجه خاص عندما نبدأ مرحلة ما يكاد يزيد على مجرد العيش .... }
$$

To explain, the translator in (23) wrongly uses the affirmed rather than the negated yakaadu, which is an approximating rather a negating marker (i.e., here it communicates the message that " $X$ is almost $Y$ "). To capture -ly negation, the translation should read لا يكاد هذا يبدو صحيحاً لموضوع مثير بوجه خاص للبحث التارئي laa yakaadu haaðaa yabduu šabiihan 


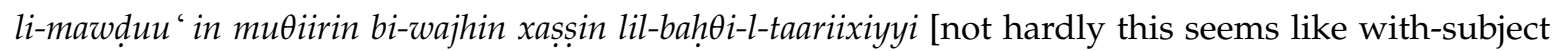
exciting with-face particular with-the-research-historical] "This hardly seems like a particularly exciting subject for historical research ... ". In (24), the translator also fails to employ a negated yakaadu, perhaps misguided by the presence of maa, which coincides, in form, with a negative particle, but is used as a relativizing marker in this sentence. To correct this mistake, the negative particle laa needs to be inserted before yakaadu in order for the Arabic translation to read wa-haaðaa ṣahiihun bi-wajhin xașșin 'indamaa nabda' u marhalata maa laa yakaadu yaziidu ' alaa mujarradi-l- 'ayši ... , which corresponds to "This is particularly true when we begin the stage which hardly goes beyond mere livelihood ... ".

\subsection{Translating Determiner Negation}

English determiner negation by little and few furnishes an utterance with a negative orientation just like too and -ly adverbial negation. They may also be used as adjectives to denote their lexical meaning by indicating smallness in size and number, respectively, which corresponds to șariir [small/little] and qaliil [little/few] in Arabic. For example, there is not much beyond their semantics in there are little children playing in the garden and The next few years will be prosperous. However, little and few are often employed as negative determiners that contrast with their positive counterparts a little and a few. Compare "There is little time for discussion" لا يو جد إلا القليل من الوقت للنقاش laa yuujadu 'illa-l-qaliilu min-al-waqti li-n-niqaaši [not exist except-the-little from-the-time for-the-discussion] with "There is a little time for discussion" يو جد بعض الوقت للنقاش “There are few mistakes in the report” لا يو جد إلا القليل من الأخطاء في التقرير laa yuujadu 'illa-l-qaliilu min-al-'axtaa'i fi-t-taqriiri [not exist except-the-few from-the-mistakes in-the-report] with There are a few mistakes in the report يوجد بعض الأخطاء في التقرير yuujadu ba'du-l-axtaa'i fi-t-taqriiri [exist some-the-mistakes in-the-report]. While little and few color the utterances with a negative orientation, $a$ little and a few color it with a positive orientation, hence the different Arabic renderings. The discussion in this section aims to show to what extent Arabic translators are aware of this subtle type of negation.

\subsubsection{Determiner Negation by Little}

Table 5 below displays the translation strategies that the translators have followed in dealing with little determiner negation.

Table 5. Frequency and percentage of translation strategies for little determiner negation.

\begin{tabular}{ccc}
\hline Translation Strategy & Frequency & Percentage \\
\hline Correct explicit negation & 33 & $38.38 \%$ \\
Incorrect implicit negation & 28 & $32.50 \%$ \\
Under-translated explicit negation & 18 & $20.95 \%$ \\
Correct implicit negation & 7 & $8.14 \%$ \\
Total & 86 & $100 \%$ \\
\hline
\end{tabular}

Out of the 99 extracted examples featuring little, 86 (86.87\%) are found to involve a negative orientation that goes beyond its denotative (dictionary) meaning. The examination of little negation data shows that the translators' attempt to handle this kind of negation involves four strategies: proper explicit negation (33 instances, 38.37\%), under-translated explicit negation (18 instances, 20.93\%), proper implicit negation (seven instances, $8.14 \%$ ), erroneous implicit negation (25 instances, 29\%), and mistranslation (one instance $(1.16 \%$ ).

To start with the first category, where determiner negation is rendered by explicit negation, which is the most frequent ( 33 instances, $38.37 \%$ ), one can notice two main translation strategies. The first (23 instances $/ 69.70 \%$ ) usually employs explicit negation, with the exception particle 'illaa or siwaa [except] 
followed by a paucity-derived word, for example, 'illaa qaliilan [except little/few] or siwaa-l-qaliila [except-the-little/few]. Consider the following example:

25. We all know that there's very little time. (TH)

$\begin{array}{lll}\text { kullu-naa na 'rifu 'anna-hu } & \text { laysa ladaynaa siwaa qaliilun min-al-waqti } \\ \text { all-we know } & \text { that-it } & \text { not have-we except little from-the-time }\end{array}$

"We all know that we don't have except little time" (i.e., "we all know that we only have little time").

$$
\text { كنا نعرف أنه ليس لدينا سوى قليل من الوقت. }
$$

The second translation strategy, which claims (10 instances, 30.30\%), employs a negated antonym, for example, lan ... al-käiira [not ... a lot/much], as is shown in the following example:

26. And all with very little effort on your part, I assure you. (HP/5)

wa-lan yakuuna 'alay-ka 'an tabðula-l-kaӨiira min-al-waqti and-not be on-you that spend-the-much from-the-time

'uțam'inu-ka

assure (I)-you

"And you won't have to spend much time, I assure you".

$$
\text { ولن يكون عليك أن تبذل الكثير من الوقت أطمئك. }
$$

One should note that Arabic can also employ belittling expressions such as laa yuðkar [not to be mentioned] or laa yastahiq-uð-ðikr [not worth mentioning] to capture the meaning of little-negation in examples like (26), which can be rephrased in (27):

27. wa-lan yakuuna 'alay-ka baðlu juhdin yastahiqqu-ð-ðikra 'uțam'inu-ka and-not be on-you making effort worth-the-mentioning assure(I)-you

"And you won't have to make (any) effort worth of mentioning, I assure you".

$$
\text { ولن يكون عليك بذل جهد يستحق الذكر أطمئن. }
$$

The second translation strategy (18 instances, 20.93\%) includes cases where the translator succeeds in recovering Arabic explicit negation but, unfortunately, misses the focus of determiner negation (i.e., he/she under-translates this subtle type of negation). By way of illustration, witness the following example:

28. The truth was, I had very little idea how dangerous things were. (TH)

$\begin{array}{lll}\text { fi-l-haqiiqati } & \text { lam 'akun 'a 'rifu madaa xutuurati-1-'amri } \\ \text { in-the-fact } & \text { not } & \text { be know(I) extent dangerousness-the-situation }\end{array}$

"In fact, I didn't know how dangerous the situation was".

$$
\text { في الحقيقة لم أكن أعرف مدى خطورة الأمر. }
$$

As can be seen, little-negation in (28) is rendered in Arabic to what corresponds to not negation in English, thus missing the nuance of this type of negation. To capture this nuance, the Arabic rendering should employ an exception expression along with explicit negation as in (29):

29

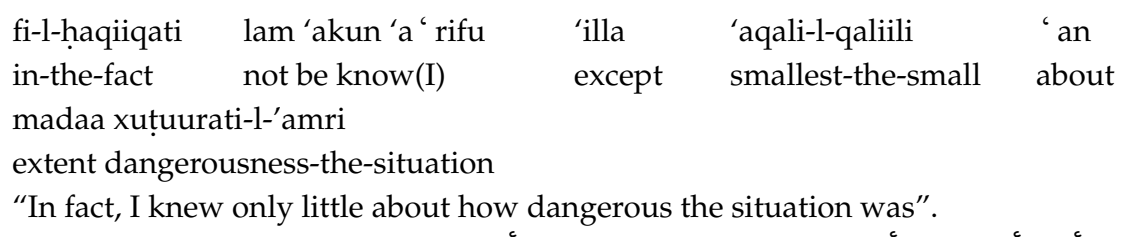

$$
\text { في الحقيقة لم أكن أعرف إلا أقل القليل عن مدى خطورة الأمر. }
$$

The next two strategies involve the translator's attempt to render little negation by implicit negation. The outcome is far from being impressive: Only seven cases $(8.14 \%)$ may be considered 
successful in implementing this strategy, while 28 cases (32.50\%) falter in this respect. Following are two examples where the first succeeds in relaying little negation (30), while the second falters (31):

30. "You know that Father punishes you very little", said Sidonie coaxingly. (BF)

'anta ta 'rifu yaa birnaard 'anna 'abii naadiran maa yu' aaqibuka ...

you know oh Bernard that father(my) rarely punish(you)

"You know Bernard that my father rarely punishes you ..."

$$
\text { أنت تعرف يا بيرناد أن أبي نادراً ما يعاقبك .... }
$$

31. Very little has changed with her health. (TH)

$$
\begin{array}{lll}
\text { laqad } & \text { țara'a } & \text { tahassunun 'alaa șiḥhati-haa } \\
\text { ? } & \text { happened } & \text { improvement on health(her) }
\end{array}
$$

"Her health has improved".

$$
\text { لقد طرأ تحسن على صحتها. }
$$

In (30), the translator employs the paucity expression naadiran maa [rarely] to capture the meaning of little negation. By contrast, the Arabic rendering in (31) embraces a positive orientation towards the referent's health conditions, which runs counter to the negative orientation in the English utterance.

\begin{tabular}{|c|c|c|c|}
\hline $\begin{array}{l}\text { lam yatra' } \\
\text { not happened }\end{array}$ & $\begin{array}{l}\text { tahassunun } \\
\text { improvement }\end{array}$ & $\begin{array}{l}\text { yastahiqqu- } \partial-ð \mathrm{ikra} \\
\text { worth-the-mentioning }\end{array}$ & $\begin{array}{l}\text { 'alaa } \\
\text { on }\end{array}$ \\
\hline
\end{tabular}
To capture this orientation, the Arabic rendering may be rephrased using explicit negation along with a belittling expression as in (32) below:

32.

"There wasn't any improvement worth mentioning about her health".

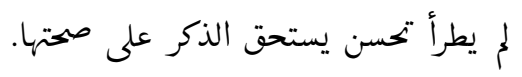

\subsubsection{Determiner Negation by Few}

Table 6 below presents the frequency and percentage of translation strategies which the translators have employed in rendering few determiner negation.

Table 6. Frequency and percentage of translation strategies for few determiner negation.

\begin{tabular}{ccc}
\hline Translation Strategy & Frequency & Percentage \\
\hline Incorrect implicit negation & 12 & $60 \%$ \\
Correct explicit negation & 7 & $35 \%$ \\
Correct implicit negation & 1 & $5 \%$ \\
Total & 20 & $100 \%$ \\
\hline
\end{tabular}

Negation by few is the least frequent in the corpus. Out of 93 extracted examples involving the employment of few, only 20 are found to furnish the English utterance with a negative orientation. In the rest of the examples, the determiner few reflects its dictionary meaning, which corresponds to qaliil [few] in Arabic, without any coloration of negation. In such cases, the rendering of few into Arabic is straightforward, as no negation is to be accounted for. The following example is illustrative:

33. The next few weeks is real important for Mae Mobley. (TH)

kaanat-il-'asaabii ' u-l-qaliilatu-t-taaliyatu haamatan jiddan binnisbati 'ilaa maw muublii were-the-weeks-the-few-the-next important very as regards to Mae Mobley

"The next few weeks were very important for Mae Mobley".

$$
\text { كانت الأسابيع القليلة التالية هامة جدا بالنسبة إلى ماو موبلي. }
$$


However, when few is employed as a negative determiner, which is meant to express the producer's unfavorable attitude towards the state of affairs in question, explicit Arabic negation may be needed. The data shows that explicit negation has been correctly employed in seven instances $(35 \%)$, while implicit negation is erroneously employed in 12 instances $(60 \%)$, and only once correctly $(5 \%)$. The two examples below are representative of the success and failure in rendering few negation:

34. They stopped at no inns, and exchanged very few words. (BF)

\begin{tabular}{|c|c|c|c|}
\hline $\begin{array}{l}\text { lam yatawaqqafaa } \\
\text { not stopped(dual) }\end{array}$ & $\begin{array}{l}\text { 'inda } \\
\text { at }\end{array}$ & $\begin{array}{l}\text { 'ayyi haanatin } \\
\text { any inn }\end{array}$ & $\begin{array}{l}\text { wa-lam yatabaadalaa } \\
\text { and-not exchanged }\end{array}$ \\
\hline
\end{tabular}
min-al-kalimaati from-the-words

"They didn't stop at any inns and didn't exchange but few words".

$$
\text { لم يتوقفا عند أي حانة ولم يتبادلا إلا القليل من الكلمات. }
$$

35. And there are as yet few business models for journalism originating on the Internet. (GC)

\begin{tabular}{|c|c|c|}
\hline wa-hunaaka & 'adadun qaliilun & min namaaðiji-1-'a ' maali-ṣ-ṣahafiyyati \\
\hline $\begin{array}{l}\text { and-there } \\
\text { an-naaši'ati }\end{array}$ & 'ala-l-intarnit & \\
\hline the-new & on-the-Internet & \\
\hline
\end{tabular}

$$
\text { وهناك حتى الآن عدد قليل من نماذج الأعمال الصحفية الناشئة على الإنترنت. }
$$

As is clear in (34) above, the translator has duly accessed explicit negation along with an exception expression in Arabic to account for few negation. By contrast, the translator has failed to invest explicit negation and, consequently, opts erroneously for an affirmative utterance in (35). The competent reader can readily feel the missing negative orientation in the rendering due to the translator's failure to capture the pragmatics of few negation. To remedy this situation, explicit Arabic negation along with an exception expression may be accessed to furnish a negative orientation (36 below):
36. wa-laa yuujadu hatta-l'aan 'illaa 'adadun qaliilun min namaaðiji-l-'a ' maali-ṣiḥhati-haa
an-laa exist till-now except number small from models-the-businesses
ṣ-ṣa hạafiyyati an-naaši'ati 'ala-l-intarnit
the-journalism the new the-journalism
"There aren't as yet but few new business models on the Internet".

$$
\text { ولا يو جد حتى الآن إلا عدد قليل من نماذج الأعمال الصحفية الناشئة على الإنترنت. }
$$

\section{Discussion}

In response to the first research question concerning how Arabic translators tackle too adverbial negation (which is formally missing in Arabic) and what translation strategies they employ, the study shows that they resort to explicit negation and implicit negation as two general strategies. This clearly proves that the recovery of Arabic explicit negation is an effective translation strategy in dealing with too negation. Within explicit negation, three strategies are employed: unpacking by coordination, nominalization, and indicating degree of attribute.

Unpacking by coordination turns out to be a very effective translation strategy for rendering too negation. The translators have successfully managed to explicate the English negation encapsulated in the negative marker too by using a consequential coordinate clause involving explicit negation. In this way, for example, the too negation in Harry was too deeply asleep to hear her is successfully relayed into an Arabic rendering that back-translates into Harry was deeply asleep, so he didn't hear her, which is an alternative English textualization that employs generic explicit negation. Arabic translators; therefore, need to be fully aware of this workable strategy when dealing with too negation. 
Resorting to explicit negation by nominalizing the English verb in a simple or complex Arabic structure also proves to be a workable translation strategy for rendering too negation. For example, the translator has managed to recover Arabic generic negation by nominalizing the English verb save into the Arabic verbal noun 'inqaaði "saving", in I was too late to save the girl, into a simple Arabic structure which literally back-translates into *I couldn't saving the girl. Similarly, the translator has successfully nominalized the verb drive away, in but his Patronus was too feeble to drive the dementor away, in the English infinitive clause, into 'ib 'aadi (driving away) in an Arabic complex structure (which back-translates into a workable English textualization, viz. but his Patronus wasn't strong enough to drive the dementor away).

Indicating the degree of the attribute in question, for its part, presents itself as a very useful translation strategy when rendering too negation by explicit Arabic negation. It corresponds to an awkward English textualization that may paraphrase too negation. For example, the Arabic idiomatic rendering of Professor Trelawney seemed too tipsy to have recognized Harry back-translates into the awkward English paraphrase Professor Trelawney was drunk to the extent that she didn't recognize Harry.

There are few cases when the translator's recovery of Arabic generic negation does not convey the nuance of too negation properly. For example, the too negation in but Harry was too used to this to care is rendered into Arabic explicit negation that back-translates into but Harry didn't care about this, thus doing away with the shade of meaning inherent in too negation. To capture this shade of meaning, the translator could have indicated the degree of the attribute in question by offering an Arabic rendering that back-translates into the English paraphrase but Harry was used to this to the extent that he didn't care or, alternatively, the translator could have unpacked too negation by coordination by offering what back-translates into Harry was used to this, so he didn't care.

As for implicit negation, it is not as successfully employed as explicit negation. However, this does not mean that implicit negation is not a viable option; it just suggests that it needs to be utilized more carefully by calling up three strategies: use of comparative form, use of negative, and indication of degree of attribute, which prove to be effective in rendering too negation.

The employment of the comparative form idiomatically renders many cases of too negation. For instance, the English too negation in because it was too long to memorize is correctly relayed into Arabic to what back-translates into an English workable textualization, viz. because it was longer than it could be memorized. Similarly, the use of negative verbs/verbals may appropriately capture too negation. The English too negation in Anna dies or becomes too ill to continue writing it, for example, lends itself to translating by employing a negative verb whose semantics takes care of negation, viz. the Arabic rendering back-translates into Anna died or reached a degree of illness that prevented her from continuing writing. Likewise, employing set formulas to indicate the degree of the relevant attribute succeeds in capturing too negation implicitly. Notice how the Arabic rendering, whose back-translation is the fines for violations were so small that they lost their effect, proves to be an idiomatic translation of the too negation in Fines for violations were too small to be effective.

Despite the successful employment of these strategies, the translators have failed to use implicit negation correctly in about one third of the cases. This makes the strategy of implicit negation more challenging than that of explicit negation. Therefore, the translator's first strategy should be to consider explicit negation, and he/she needs to exercise utmost care when opting for implicit negation. For example, the too negation should not be confused with the negation-free intensifier jiddan "very". In this way, the too negation in It is still far too cold to undress at night should not be rendered in Arabic

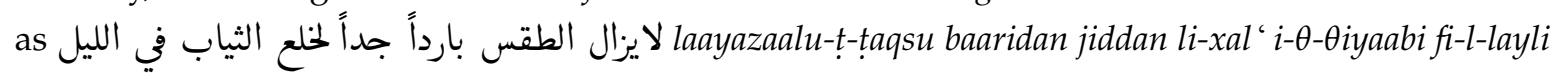
"**The weather is still very cold to take off clothes at night." To use Arabic implicit negation properly, the translator could have employed an Arabic negative verb whose semantics takes care of too negation, viz. kaan-al-jawwu-l-baaridu yamna "u-naa min xal 'i malaabisi-naa fi-l-layli "The cold weather prevented us from taking off our clothes at night."

To address the second research question concerning the translation strategies in rendering -ly negation, the data shows that the successful use of explicit negation and implicit negation accounts 
for only $(37.50 \%)$ in the corpus. The rest of the cases goes for the vernacular bilkaad (31.70\%), which is ungrammatical, and mistranslations/under-translations/omission (31.75\%). This clearly shows how problematic rendering -ly negation into Arabic is. To render this type of negation properly, translators into Arabic need to be made aware of the negated Arabic verb yakaadu when employing explicit negation, as well as paucity/difficulty expressions when opting for implicit negation. Only then can the pragmatics of -ly negation be captured in Arabic.

Arabic negation by explicit negative particles emerges as the most common translation strategy for rendering the -ly negative adverbs, which clearly indicates the translators' awareness of their negative orientation. However, the coding of this orientation in Arabic seems to be a challenging task. In fact, more than half involves under-translating this adverbial negation by rendering it into what corresponds to negation by not in English. In this way, the subtle nuance of this type of negation is lost in translation.

To employ explicit negation properly when dealing with -ly negation, the translator needs to access the Arabic negated verb yakaadu, which does not seem to be an easy task. Apparently, Arabic translators more often than not fall in the trap of under-translation by offering English generic negation by not, viz. The Barn didn't heed her (back-translation of Arabic translation) for Frefrau scarcely heeded

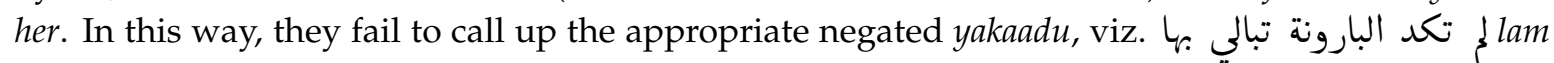
takad al-baaruunatu tubaali bi-haa "The Baroness scarcely/hardly heeded her". Älternatively, they are erroneously attracted by the vernacular bilkaad, which is a negative adverb commonly used in most Arabic vernaculars for this type of negation. This option reflects the translator's deficient knowledge of Standard Arabic, which has its standard version (the negated yakaadu verb) for the vernacular bilkaad. Arabic translators; therefore, need to be cautioned against rendering $l y$-negation into the generic not negation as well as the use of vernacular bilkaad.

Arabic implicit negation may also be considered when translating -ly negation. When implementing this translation strategy, the translator needs to call up Arabic paucity expressions such as naadiran maa / qallamaa "rarely" or the difficulty expression bi-șu "uubatin which approximates than replicates -ly negation implicitly. Though implicit negation is used much less frequently than explicit negation where several errors are made, it proves to be very appropriate in some cases, especially when the translator utilizes paucity expressions.

To respond to the third research question regarding the rendering of little determiner negation, results show that the success rate is less than $50 \%$, which clearly indicates how problematic little negation is when relaying it into Arabic.

The most effective translation strategy when employing explicit negation is to use exception expressions combined with paucity words, which can properly capture this kind of subtle negation. Arabic translators; however, need to be cautioned against falling in the trap of under-translating little negation into what corresponds to English not negation, viz. The truth was, I had very little idea how dangerous things were may wrongly be translated into an Arabic rendering that back-translates into In fact I didn't know how dangerous the situation was, a mishap which belies several cases of little negation. To capture little negation here, the translator needs to use explicit negation along with an exception

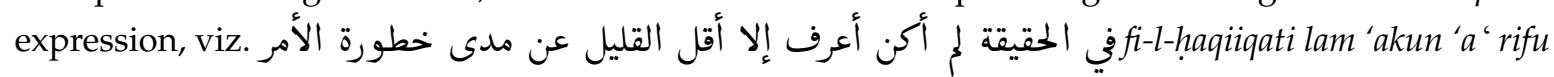
'illa 'aqalli-l-qaliili 'an madaa xuṭurati-l-'amri, which back-translates into In fact I knew only very little about how dangerous the situation was.

Negated antonyms may also be used to relay little negation explicitly, though at a lesser degree of success, viz. And all with very little effort on your part, I assure you relatively corresponds to the Arabic rendering that back-translates into And you won't have to spend much effort, I assure you. However, the employment of explicit negation with a belittling expression such laa yastahiqu-ið-ðikr "not worth mentioning" can be a more effective strategy for capturing the shade of meaning in little negation than using explicit negation with a negated antonym, viz. ولن يكون عليك أن تبذل الكثير من الوقت أطمئن wa-lan yakuuna 'alay-ka 'an tabðula-l-kaAiira min-al-waqti 'utam'inu-ka, which back-translates into And 
you won't have to make a lot of effort, I assure you. Consequently, the Arabic translator needs to be alerted to the importance of using exception expressions as well as belittling expressions when using explicit negation in rendering little negation.

As for implicit negation, which is employed in only few cases, it resorts to expressions inherently marked for paucity such as naadiran maa/qallamaa "rarely" independently of negative particles. The bulk of cases; however, indicates that the translators are only little aware of the negative orientation furnished by little negation. In fact, the erroneous translations furnish a positive rather negative orientation of little negation. For example, the rendering of Very little has changed with her health in لقد طرأ تحسن على صحتها laqad țara'a tahassunun 'alaa șihhati-haa into Her health has improved has completely deprived the Arabic translation of the negative orientation. It is of utmost importance; therefore, to alert Arabic translators to the need to recover explicit negation along with paucity or belittling expressions to capture little negation. In this way, the above example should be rendered as lam yatra' tahassunun yuðkaru' alaa șihhati-haa, which back-translates into There wasn't any improvement worth mentioning with her health.

Finally, in response to the fourth research question, the results show that few determiner negation proves to be so problematic in Arabic translation. This finding clearly points to the challenging subtlety of few negation which needs to be brought to the consciousness of Arabic translators who are supposed to be aware of the difference between few as a negative operator and few as a mere determiner. Apparently, the translators are not aware of the need to recover explicit Arabic negation along with an exception expression to relay the negative attitude encapsulated in this type of subtle negation. The attempt to employ implicit negation has failed except in one instance, which clearly indicates that explicit rather than implicit negation is the appropriate translation strategy to use when rendering few negation. Translators into Arabic; therefore, need to be sensitized to the nature of few negation and the appropriate strategies that may be used to render its pragmatics.

\section{Conclusions}

Tables 2-6 report my judgments about the success and competence of translators whose work I examined for this study. The findings show evidence that the pragmatics of this type of English negation is a challenging task in translation activity. Arabic translators, both professionals and more so student translators, need to be alerted to the fact that this type of negation, which formally does not exist in Arabic (and probably in several other languages), calls, in the first place, for recovering generic negation and, in the second place, for appropriately investing implicit negation in Arabic. Only then can the negative orientation, with which adverbial and determiner negation furnishes English utterances, be captured in Arabic translation.

In response to the research questions, the study has uncovered a rich spectrum of translation strategies that Arabic translators may employ to deal with non-generic English adverbial and determiner negation, which is found to be a problematic area representing a textual mismatch between English and Arabic. The translation strategy of recovering generic explicit negation in Arabic presents itself as a first priority that cuts across all types of non-generic adverbial and determiner negation. For its part, implicit negation may also cut across all types of non-generic adverbial and determiner negation, but to a lesser extent, when rendering it into Arabic. Since it is semantically based, it seems to be more challenging to Arabic translators.

Funding: This research was supported by Kuwait University, Research Grant No. [AE03/16].

Conflicts of Interest: The author declares no conflict of interest.

\section{Appendix A. List of Arabic Phonetic Symbols}

/b/ voiced bilabial stop

$/ \mathrm{m} /$ bilabial nasal 
/f/ voiceless labio-dental fricative

$/ ð /$ voiced interdental fricative

$/ \underline{\delta} /$ voiced interdental emphatic fricative

$/ \theta /$ voiceless interdental fricative

/d/ voiced alveolar stop

/ $t$ / voiceless alveolar stop

/d / voiced alveolar emphatic stop

/ț/ voiceless alveolar emphatic stop

/ $\mathrm{z} /$ voiced alveolar fricative

/s/ voiceless alveolar fricative

/s / voiceless alveolar emphatic fricative

$/ \mathrm{n} /$ alveolar nasal stop

$/ \mathrm{r} /$ alveolar rhotic liquid

/1/ alveolar lateral liquid

/š/ voiceless alveo-palatal fricative

$/ \mathrm{j} /$ voiced palatal affricate

/y/ palatal glide

/w/ labio-velar glide

/g/ voiced velar stop

$/ \mathrm{k} /$ voiceless velar stop

$/ \gamma /$ voiced uvular/post-velar fricative

$/ \mathrm{x} /$ voiceless uvular/post-velar fricative

/q/ voiceless uvular stop

/ / voiced pharyngeal fricative

/h/ voiceless pharyngeal fricative

/'/ glottal stop

$/ \mathrm{h} /$ voiceless laryngeal fricative

/i/ high front short vowel

$/ \mathrm{u} /$ high back short vowel

/a/ low half-open front-to-centralized short vowel

/ii/ high front long vowel

/uu/ high back long vowel

/aa/ low open front-to-centralized long vowel

/ee/ mid front long vowel

/oo/ mid back long vowel

\section{References}

Al-Ghazalli, Mehdi Falih. 2013. Translation Assessment of Arabic Implicit Negation into English. International Journal of English Linguistics 3: 129-44. [CrossRef]

Al-Makhzumi, Mahdi. 2016. Arabic Grammar: A Critical Account. Baghdad: Cultural Affairs House for Publication.

Alsalem, Esgha. 2012. Negation in Standard Arabic and Kuwaiti Arabic. Master's thesis, University of Illinois at Urbana-Champaign, Champaign, IL, USA.

Anees, Ibriham. 1975. From the Secrets of the Language. Cairo: Anglo Egyptian Library.

Apostolatu, Rodica-Cristina, and Ionel Apostolatu. 2012. Linguistic and Cultural Issues in Translating Negation in Literary Texts: A Case Study, Mourning Becomes Electra, by Eugene O'Neill. Procedia Social and Behavioral Sciences 63: 63-68. [CrossRef]

Baker, Mona. 1992. In Other Words. London: Longman.

Catford, John Cunnison. 1965. A Linguistic Theory of Translation. Oxford: Oxford University Press. 
Clark, Herbert. 1976. Semantics and Comprehension. The Hague: Mouton.

Dahl, Östen. 1979. Typology of Sentence Negation. Linguistics 17: 79-106. [CrossRef]

Dendane, Zoubir, and Amine Dendane. 2012. The Negation in Arabic: An Issue for Translation. Revue Maghrébine des Langues 8: 199-212.

Dickins, James, Sándor Hervey, and Ian Higgins. 2002. Thinking Arabic Translation. London and New York: Routledge.

Farghal, Mohamm. 2012. Advanced Issues in Arabic-English Translation Studies. Kuwait: Kuwait University Publication Council.

Farghal, Mohammed, and Ali Almanna. 2015a. The Linguistics of Translation. In Papers in Arabic/English Translation Studies 1: An Applied Perspective. Jordan: Jordanian Translators' Association.

Farghal, Mohammed, and Ali Almanna. 2015b. Contextualizing Translation Theories: Aspects of Arabic-English Interlingual Communication. London: Cambridge Scholars Publishing.

Farghal, Mohammed; et al. 2015. Papers in Arabic/English Translation Studies 1: An Applied Perspective. Jordan: Jordanian Translators' Association Publication.

Fitzgerald, Penelope. 1995. The Blue Flower. New York: Flamingo, Translated by Ali M. Suleiman. 2015. As The Blue Flower. Kuwait: Ibda'at Alamiya (World Masterpieces).

Gore, Al. 2013. The Future: Six Drivers of Global Change. New York: Random House, Translated by Adnan Gergeos. 2015. As The Future: Six Engines of Global Change. Kuwait: Aalam Al-Ma'rifah Series.

Green, John. 2012. The Fault in Our Stars. New York: Dutton Books, Translated by Baseel Intwan. 1975. As What the Stars Hide for Us. Beirut: Publishing and Distribution Company.

Hatim, Basil. 1997. Communication across Cultures: Translation Theory and Contrastive Text Linguistics. Exeter: University of Exeter Press.

Heilbroner, Robert. 1962. The Making of Economic Society. Englewood Cliffs: Prentice-Hall, Translated by Rashid Al-Barrawi. 1976. As How Do we Make Economic Society to Achieve Development. Beirut: Arab Consciousness Bookstore.

Horn, Laurence. 2001. A Natural History of Negation. Chicago: University of Chicago Press.

Horn, Laurence R., and Yasuhiko Kato. 2000. Introduction: Negation and Polarity at the Millennium. In Studies in Negation and Polarity. Oxford: Oxford University Press, pp. 1-19.

Klima, Edward. 1964. Negation in English. In The Structure of Language. Upper Saddle River: Prentice-Hall, pp. 246-323.

Koller, Werner. 1979. Equivalence in Translation Theory. Translated from German by A. Chesterman. In Readings in Translation Theory. Helsinki: Finn Lectura, pp. 99-104.

Li, David. 2017. Multilingual Hong Kong: Languages, Literacies and Identities. Cham: Springer.

Munday, Jeremy. 2012. Introduction to Translation Studies. London and New York: Routledge.

Muslah, Alham. 2015. Implicit Negation in Selected Romantic Poem in English and Arabic: A Contrastive Study. Al-Bahith Journal 14: 366-82.

Newmark, Peter. 1988. A Textbook of Translation. London: Prentice Hall.

Nida, Eugene Albert. 1964. Toward a Science of Translating. Leiden: Brill.

Payne, John. 1985. Negation: Language Typology and Syntactic Description. In Clause Structure. Cambridge: Cambridge University Press, pp. 197-242.

Pym, Anthony. 2010. Exploring Translation Theories. London and New York: Routledge.

Rowling, J. K. 1997. Harry Potter and the Philosopher's Stone. UK: Bloomsbury, Translated by Ragaa Abdullah. 2017. As Harry Potter and the Philosopher's Stone. Cairo: Egypt Company for Printing and Publication.

Rowling, J. K. 1998. Harry Potter and the Chamber of Secrets. New York: Scholastic Press, Translated by Ragaa Abdullah. 2008. As Harry Potter and the Chamber of Secrets. Cairo: Egypt Company for Printing and Publication.

Rowling, J. K. 1999. Harry Potter and the Prisoner of Azkaban. New York: Scholastic Press, Translated by Hasan M. Ahmed. 2018. As Harry Potter and Azkaban Prisoner. Cairo: Egypt Company for Printing and Publication.

Rowling, J. K. 2003. Harry Potter and the Order of Phoenix. New York: Scholastic Press, Translated by Idaarit Al-Nashr. 2008. As Harry Potter and the Group of Phoenix. Cairo: Egypt Company for Printing and Publication.

Rowling, J. K. 2005. Harry Potter and the Half Blood Prince. New York: Scholastic Press, Translated by Abd Al-Wahab Aloob. 2009. As Harry Potter and the Hybrid Prince. Cairo: Egypt Company for Printing and Publication. 
Stockett, Kathryn. 2009. The Help. London: The Penguin, Translated by Hassan Al-Bustani. 2010. As The Housemaid. Beirut: Arab House Publishers.

Vinay, Jean-Paul, and Jean Darbelnet. 1995. Comparative Stylistics of French and English: A Methodology for Translation. J. Sager, and M. HamelAmsterdam and Philadelphia: John Benjamins, Originally published as 1958. Stylistique Comparee du Francais et de L'anglais: Methode de Traduction. Paris: Didier. 